\title{
Isotherm and Kinetics of Cd(II) Adsorption by Durian (Durio zibethinus) seed Immobilized into Ca-alginate
}

\author{
Intan Lestari \\ Department of Chemistry, Jambi University, Jambi, Indonesia
}

\begin{abstract}
Purpose - The purpose of this paper to immobilization provides biosorbent particle with density and mechanichal strength, immobilization can save the cost of separating from biomass, can be regeneration and to increase adsorption capacity for metal ions.

Design/Methodology/Approach - The parameters affecting the adsorption, such as initial metal ion concentration, $\mathrm{pH}$, contact time, and temperature, were studied. The analysis of biosorbent functional group was carried out by Fourier Transform Infrared Spectroscopy, SEM-EDX, for elemental analysis.

Findings - Optimum $\mathrm{pH}$ condition for biosorption $\mathrm{Cd}(\mathrm{II})$ was $\mathrm{pH}$ 5, contact time was $45 \mathrm{~min}$, and initial concentration was $250 \mathrm{mg} / \mathrm{L}$. Biosorbent analysis was characterized using SEM-EDX and FTIR analysis. Kinetics adsorption was studied and analyzed in terms of the pseudo-first-order, pseudo-second-order, and intraparticle diffusion kinetics models. The result showed that the biosorption for $\mathrm{Cd}(\mathrm{II})$ ion followed the pseudo-second-order kinetic model. Biosorption data of $\mathrm{Cd}(\mathrm{II})$ ion at $300^{\circ} \mathrm{K}, 308^{\circ} \mathrm{K}$, and $318^{\circ} \mathrm{K}$ was analyzed with Temkin, Langmuir, and Freundlich isotherms. Biosorption of $\mathrm{Cd}(\mathrm{II})$ by durian seed immobilization in alginate according to the Langmuir isotherm equation provided a coefficient correlation of $r^{2}=0.939$ and maximum capacity biosorption of $25.05 \mathrm{mg} / \mathrm{g}$.
\end{abstract}

Keywords Biosorption, Durio zibethinus seed, Ca-alginate, immobilization

All papers within this proceedings volume have been peer reviewed by the scientific committee of the Malikussaleh International Conference on Multidisciplinary Studies (MICoMS 2017).

\section{Introduction}

Contamination of aquatic environments by heavy metals is caused by the disposal of industrial wastewater. Some heavy metals are quite dangerous, such as $\mathrm{Pb}, \mathrm{Cd}$, and $\mathrm{Hg}$. Cadmium is an unnecessary element for plants and animals, and is not degradable and transferable through the food chain. Waste stream from smelting, alloying, pigments, batteries, plastics, mining, and refining processes are the main sources of cadmium release into the environment. Cadmium is a toxic metal that contaminates the environment and does not degrade naturally, causing serious problems in the environment. Therefore, cadmium ion must be removed from the industrial waste.

(C) Intan Lestari. Published in the Emerald Reach Proceedings Series. Published by Emerald Publishing Limited. This article is published under the Creative Commons Attribution (CC BY 4.0) licence. Anyone may reproduce, distribute, translate and create derivative works of this article (for both commercial and non-commercial purposes), subject to full attribution to the original publication and authors. The full terms of this licence may be seen at http://creativecommons.org/licences/by/4.0/ legalcode
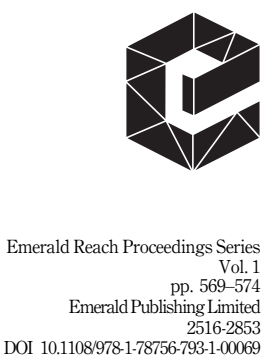
Proceedings of MICoMS 2017
There are several chemical and physical methods used to reduce cadmium, including precipitation method, membrane process, adsorption, ion-exchange floating, and others (Kefala et al., 1999; Selatnia et al., 2004). However, several methods have such limitations as being less efficient, resulting in further disposed secondary sludge and expensive operating costs (Ahluwalia et al., 2005). One alternative technique is biosorption (Volensky, 2007), in which some types of biomaterial can bind metals even at very dilute concentrations (Martinez et al., 2006).

Some biological materials have been studied in the biosorption of heavy metal ions in water, such as seaweed, algae, fungi, and microorganisms, both living cells and nonliving cells (Volensky, 2007).

Some of the agricultural waste used as heavy metal biosorbents include jackfruit seeds for $\mathrm{Pb}$ (II) (Okolo et al., 2012), soursop fruit (Annonamuricata) for $\mathrm{Cd}$ (II) and $\mathrm{Zn}$ (II) ions (Rahmadani et al., 2013), durian skin for Cd(II) (Saekaew, 2010), and durian seeds for Zn(II) biosorption (Lestari et al., 2015).

Durian seed was selected as a biosorbent because it is an agricultural waste present in abundance. Durian (Durio zibethinus) seed consists of holocellulose $(26.4 \%)$, cellulose $(60.5 \%)$, and hemiselose (13.1\%) (Ahmad et al., 2014); these characteristics can be utilized as biosorbent metal ions.

Alginate is an anionic copolysaccharide consisting of residues of $\beta$-1-4-D-manuronate (M) and $\alpha$-L-guluronate $(\mathrm{G})$. Alginate is a natural polysaccharide commonly present in the cell walls of all species of brown algae (Phaeophyceae), nontoxic, degradable, and biocompatible (Verma et al., 2013). The purpose of this study was to immobilize durian seeds with Caalginate and use them for adsorption of $\mathrm{Cd}(\mathrm{II})$ ion from aqueous solutions by batch experiment and evaluate the effects of contact time, $\mathrm{pH}$ variable, initial concentration cadmium ions, and temperature of the solution.

\section{Methods}

\subsection{Biosorbent preparation}

Durian seeds were collected from a local market durian located in the Padang City, West Sumatra, Indonesia. Durian seed sample was processed by washing with deionized water. The washed material was cut into small pieces $(1-2 \mathrm{~cm})$ and then dried in an oven at $60^{\circ} \mathrm{C}$ until it reached a constant weight. The dried sample was finely grounded using a grinder, saturated with a particle of $71 \mu \mathrm{m}$, and activated with $\mathrm{HNO}_{3} 0.1 \mathrm{M}$ for $2 \mathrm{~h}$, filtered, and dried again.

\subsection{Immobilization of durian seeds in Ca-alginate}

The procedure used is based on the reference method of Lestari et al. (2016). Biosorbent durian seeds immobilized into Ca-alginate were characterized before and after sorption by FT-IR Spectrometer (Perkin Elmer System, 2000). Surface morphology of biosorbent was analyzed by a scanning electron microscopy (SEM), and the photograph was taken using the JSM-JSM-5410 LV model.

\subsection{Batch biosorption experiment}

2.3.1. Effect of $p H$ solution. The effect of the $\mathrm{pH}$ solution was determined from a $\mathrm{pH}$ of 2 to 7 , with agitation of $0.1 \mathrm{~g}$ biosorbent and $20 \mathrm{~mL} \mathrm{Cd(II)} \mathrm{with} \mathrm{a} 10 \mathrm{mg} / \mathrm{L}$ concentration by using a shaker. Contact time of agitation was $60 \mathrm{~min}$ with an agitation rate of $150 \mathrm{rpm}$ at $25^{\circ} \mathrm{C} . \mathrm{pH}$ was adjusted by adding $0.1 \mathrm{~N} \mathrm{NaOH}$ or $0.1 \mathrm{~N} \mathrm{HNO}_{3}$.

2.3.2. Effect of contact time. The contact time was determined by stirring $0.1 \mathrm{~g}$ biosorbent and $20 \mathrm{~mL} \mathrm{Cd(II)} \mathrm{with} \mathrm{a} \mathrm{concentration} \mathrm{of} 10 \mathrm{mg} / \mathrm{L}$ by using a shaker at $\mathrm{pH} 5$. The contact time of agitation was set to $5-120 \mathrm{~min}$ with a stirring speed of $150 \mathrm{rpm}$ at $25^{\circ} \mathrm{C}$. 


\subsection{Isotherm experiments}

Equilibrium isotherm was determined by stirring $0.1 \mathrm{~g}$ biosorbent with $\mathrm{Cd}(\mathrm{II})$ at a concentration of $10-250 \mathrm{mg} / \mathrm{L}$ using a shaker at $\mathrm{pH}$ 5. The agitation contact time was 45 min, with a constant agitation rate of $150 \mathrm{rpm}$ and a temperature of $25-45^{\circ} \mathrm{C}$. The absorption capacity of $\mathrm{Cd}(\mathrm{II})$ was determined by using a mass balance. The adsorption capacity of $\mathrm{Cd}$ (II) can be calculated as:

$$
\mathrm{Q}_{e}=\left(\mathrm{C}_{i}-\mathrm{C}_{e}\right) \cdot \mathrm{V}
$$

Isotherm and Kinetics of $\mathrm{Cd}$

where $\mathrm{Qe}=$ uptake capacity $\mathrm{Cd}(\mathrm{II})$ at the equilibrium $(\mathrm{mg} / \mathrm{g}), \mathrm{V}=$ volume of $\mathrm{Cd}(\mathrm{II})(\mathrm{mL})$ solution, $\mathrm{m}=$ biosorbent mass $(\mathrm{g}), \mathrm{C}_{\mathrm{i}}=$ initial concentration $\mathrm{Cd}(\mathrm{II})(\mathrm{mg} / \mathrm{L})$, and $\mathrm{Ce}=$ concentration $\mathrm{Cd}(\mathrm{II})$ at equilibrium $(\mathrm{mg} / \mathrm{L})$.

\section{Results and discussion}

\subsection{Result}

3.1.1. Effect of $p H$. $\mathrm{pH}$ is an important parameter in the biosorption process (Wan Ngah et al., 2002). Effects of $\mathrm{pH}$ on the uptake capacities of $\mathrm{Cd}(\mathrm{II})$ on alginate immobilized durian seed were investigated (Lestari et al., 2016).

3.1.2. Effect of contact time. Speed of biosorption is an important process for design experiment designed in batch. The adsorption capacity of $\mathrm{Cd}$ (II) ion can increase with increasing time and can reach an equilibrium state at 45 min with an adsorption capacity, which is is $1,9108 \mathrm{mgg}^{-1}$ (Figure 1).

3.1.3. Biosorption kinetics. The adsorption kinetics depends on sorbent-sorbate interaction and the operating conditions. Some of the kinetics models are used to study the properties of the adsorbent and the adsorption mechanism (Subbaiah, 2011). Biosorption balance data were analyzed by using kinetic adsorption pseudo-first order and pseudo-second order. The pseudo-first order can be written in the following linear form:

$$
\operatorname{Ln}(\mathrm{Q} e-\mathrm{Qt})=\mathrm{Ln} \quad \mathrm{Qe}-\mathrm{k}_{1}(\mathrm{t})
$$

where Qe and Qt (mg/g) = the amount of Cd(II) ion at the equilibrium and at time $\mathrm{t}(\mathrm{min})$, and $\mathrm{k}_{1}=$ biosorption of speed constant.

Linear equations for pseudo-second order can be written in linear form:

$$
\frac{\mathrm{t}}{\mathrm{Qt}}=\frac{1}{\mathrm{k}_{2} \mathrm{Qe}_{2}}+\frac{1}{\mathrm{Qe}} \cdot \mathrm{t}
$$

where $\mathrm{k}_{2}$ ( $\left.\mathrm{g} / \mathrm{mg} \mathrm{min}\right)$ is the second-order constant, and Qe $(\mathrm{mg} / \mathrm{g})$ and Qt are the biosorption capacities at equilibrium and at time t.

Kinetics of Cd(II) ion can be seen in Figure 2. Kinetics of Cd(II) ion on biosorption of Caalginate can follow pseudo-second-order kinetics with $\mathrm{r}^{2}=0.999$.

3.1.4. Effect of concentration of Cd(II) ion. Effect of concentration on adsorption capacity of $\mathrm{Cd}(\mathrm{II})$ ion on biosorption was studied with an initial concentration of $10-300 \mathrm{mg} / \mathrm{L}$ at $25^{\circ} \mathrm{C}$. Effect of concentration on adsorption capacity of $\mathrm{Cd}$ (II) ion can be seen in Figure 2. The amount of metal ions adsorbed per unit of biosorbent mass increases with increasing solution concentration and is optimum at $250 \mathrm{mg} / \mathrm{L}$. At a high concentration, the adsorption capacity increases due to of influence of the thrust force on metal ions toward the surface of cell wall (Fun et al.,2008). The maximum Cd(II) adsorption capacity was $25,05 \mathrm{mg} / \mathrm{g}$. 


\section{Proceedings of MICoMS 2017}

\section{2}

\section{Figure 1.}

Effect of contact time on Cd(II) uptake capacity $(\mathrm{pH}=5$, initial concentration $=10$ $\mathrm{mg} / \mathrm{L}$, stirring rate $=150 \mathrm{rpm}$ )

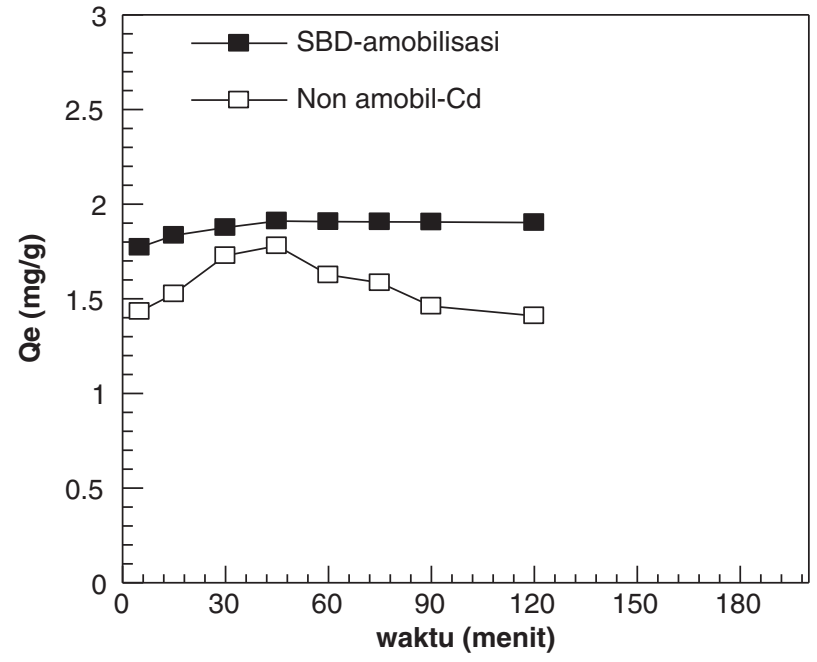

3.1.5. Isotherms adsorption ion Cd(II) The biosorption isotherm adsorption of $\mathrm{Cd}(\mathrm{II})$ is fundamental providing the essential information needed to design the adsorption process. In this research, we use the isotherm adsorption analysis by Langmuir and the Freundlich model.

3.1.6. Isotherm langmuir. Adsorption isotherm Langmuir assumes that biosorption occurs in the monolayer and can be written with the following equation:

$$
\frac{\mathrm{Ce}}{\mathrm{Qe}}=\frac{1}{\mathrm{~K}_{\max }}+\frac{1}{\mathrm{Qe}} \cdot \mathrm{Ce}
$$

where $\mathrm{K}_{\mathrm{L}}$ is the Langmuir constant associated with the adsorption energy, and Qe and $\mathrm{Q}_{\max }$ are the adsorption capacities at the equilibrium and the maximum state.

3.1.7. Freundlich isotherm. Freundlich's isotherm model describes that adsorption occurs in heterogeneous layers with interactions between adsorbate molecules. Freundlich's equation suggests that the adsorption exponential energy decreases at the adsorption center side. Freundlich isotherm empirical equation in linear form can be written as follows:

$$
\log \mathrm{Qe}=\log \mathrm{K}_{\mathrm{F}}+1 / \mathrm{n} \log \mathrm{Ce}
$$

where $\mathrm{K}_{\mathrm{F}}$ is the Freundlich related with the bond energy and $\mathrm{n}$ is the degree of adsorption linearity. Freundlich's isotherm is determined from the plot of linear log Qe versus $\log$ Ce. The value $n$ denotes the degree of nonlinearity between the concentration of the solution and the adsorption as follows: if $\mathrm{n}=1$, then linear adsorption; if $\mathrm{n}<1$, then chemical adsorption process; and if $\mathrm{n}>1$, then adsorption process occurs physically.

3.1.8. Characterization of biosorbent. The FT-IR spectrum shows wave number of peaks, indicating the properties of the adsorbent. Spectra are seen at the following bands: 3424.25 $\mathrm{cm}^{-1}$ (OH stretching vibration), $2925.51 \mathrm{~cm}^{-1}$ (OH stretching vibration), $1636.91 \mathrm{~cm}^{-1}$ (C=O 


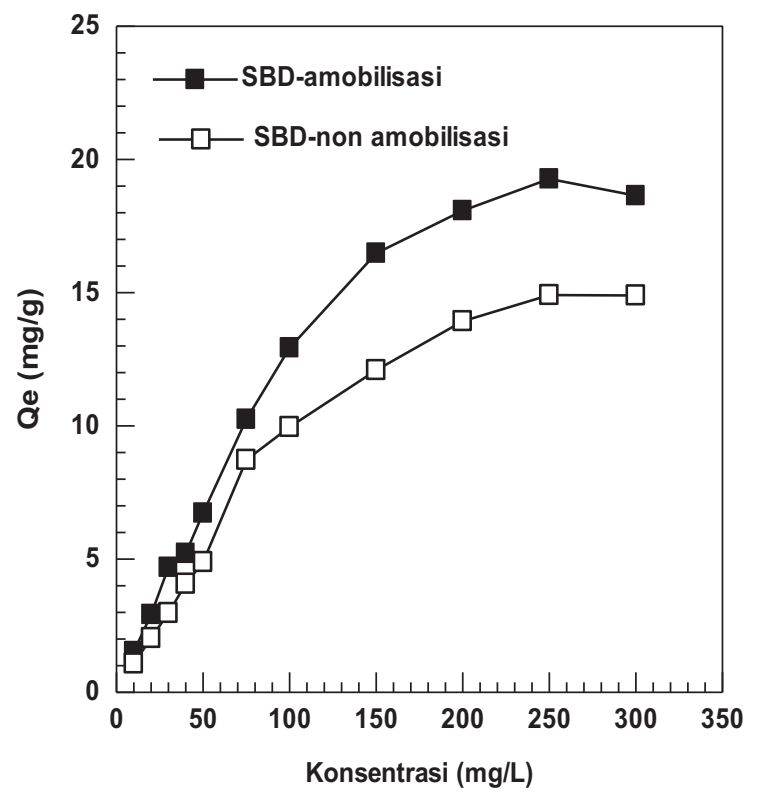

Isotherm and Kinetics of $\mathrm{Cd}$ (II)

Figure 2.

Effect of concentration on adsorption capacity $\mathrm{Cd}(\mathrm{II})(\mathrm{pHCd}=5$, volume solution $=$ $20 \mathrm{~mL}$, mass $=0.1 \mathrm{~g}$, contact time $=$ 45 minutes)

stretching of carboxylic acid vibration), $1420 \mathrm{~cm}^{-1}$ (C $=\mathrm{C}$ vibration stretch), and 1158, 1023.5 (COH stretching).

\section{Conclusion}

Durian seed was immobilized in Ca-alginate as a potential biosorbent $\mathrm{Cd}$ (II) ion in aqueous solution. Adsorption properties of a biosorbent are influenced by $\mathrm{pH}$, concentration, contact time, and temperature of the solution. Isotherm adsorption at equilibrium fitted well in the Langmuir isotherm model with a maximum adsorption capacity of $25.05 \mathrm{mg} / \mathrm{g}$. Adsorption kinetics followed the pseudo-second-order model. Characterization of the biosorbent with FT-IR spectra showed that functional groups involved in biosorption are carboxyl, hydroxyl, and carboxyl and amine groups. Durian seed immobilized in Ca-alginate can be a potential candidate for $\mathrm{Cd}(\mathrm{II})$ biosorption and further research is needed to study the biosorption process dynamically.

\section{References}

Ahluwalia, S.S. and Goyal, D. (2005), "Removal of heavy metals from waste tea leaves from aqueous solution," Eng Life Sci, Vol. 5, pp. 158-162.

Ahmad, M.A., Ahmad, A., and Bello, O.S. (2015), "Modified durian seed as adsorbent for the removal of methyl red dye from aqueous solution," Appl Water Sci, Vol. 5, pp. 407-423.

Banerjee, K., Ramesh, S.T., Gandhimati, R., Nidheesh, P.V., and Barathi, K.S. (2012), "A novel agricultural waste adsorbent, watermelon shell for the removal of copper from aqueous solution," IJEE, Vol. 3(2), pp. 143-156.

Fan, T., Liu, Y., Feng, B., Zeng, G., Yang, C., and Zhou, M. (2008), "Biosorption of cadmium(II), zinc(II) and lead(II) by Penicillium simplicissimum: Isotherms, kinetics, and thermodynamics," J Hazard Mater, vol. 160, pp. 655-661. 
Proceedings of Kefala, M.L., Zouboulis, A.L., and Matis, K.A. (1999), "Biosorption of cadmium ions by actinomycetes MICoMS 2017 and separation by flotation," Environ Pollut, Vol. 104, pp. 283-293.

Lestari, I., Sy, S., Harmiwati, Kurniawati, D., Alif, A., Munaf, E., Zein, R., and Hermansyah, A. (2015), "Equilibrium and kinetics modeling biosorption of $\mathrm{Zn}$ (II) in aqueous solution using durian (Duriozibethinus) seed as low cost biosorbent," JOCPR, Vol. 7(9S), pp. 111-122.

Lestari, I., Sy, S., Harmiwati, Kurniawati, D., Alif, A., Zein, R., and Hermansyah, A. (2016), "Effect of pH on the biosorption of heavy metal by alginate immobilized durian (Duriozibethinus) seed," Der PharmaChemica, Vol. 8(5), pp. 294-300.

574

Okolo, P.O., Irabor, E.E.I., and Abugu, T.P. (2012), "Artocarpusaltilis proving its worth in toxic metal removal from the environment," Bayero J Pure Appl Sci, Vol. 5(2), pp. 104-109.

Ong, S.T., Yip, S.P., Lee, S., and Hung, Y.T. (2012), "Papaya (Carica Papaya) seed as a low cost adsorbent for zinc removal," AJAR, Vol. 7(5), pp. 810-819.

Selatnia, A., Bakhti, M.Z., Madani, A., Kertous, L., and Mansouri, Y. (2004), "Biosorption $\mathrm{Cd}^{2+}$ from aqueous solution by a NaOH-treated bacterial dead Streptomycesrimosus biomass," Hydrometallurgy, Vol. 75, pp. 11-24.

Volesky, B. (2007), "Review biosorption and me," Water Res, Vol. 41, pp. 4017-4029.

Martinez, M., Miralles, N., Hidalgo, S., Niol, N., Villaescusa, I., and Poch, J. (2006), "Removal of lead(II) and cadmium(II) from aqueous solutions using grape stalk waste," Hazard Maters, Vol. 133, pp. 203-211.

Verma, A., Singh, A., Bishnoi, N.R., and Gupta, A. (2013), "Biosorption of $\mathrm{Cu(II)} \mathrm{using} \mathrm{free} \mathrm{and}$ immobilized biomass of Penicillium citrinum," Ecologi Engineer, Vol. 61, pp. 486-490.

\section{Corresponding author}

Intan can be contacted at ilestari_15@unja.ac.id 